\title{
Mechanisms of growth cone repulsion
}

\author{
Catherine E Krull ${ }^{1}$ and Judith S Eisen ${ }^{2 *}$
}

\author{
Addresses: ${ }^{1}$ Biologic and Materials Sciences, University of Michigan, 5211 Dental, 1011 North University Avenue, Ann Arbor, MI 48109, USA; \\ ${ }^{2}$ Institute of Neuroscience, University of Oregon, 1254 University of Oregon, Eugene, OR 97403, USA \\ *Corresponding author: Judith S Eisen (eisen@uoneuro.uoregon.edu) \\ FI000 Biology Reports 2010, 2:6 (doi:10.34I0/B2-6)
}

The electronic version of this article is the complete one and can be found at: http://fl 000.com/reports/biology/content/2/6

\begin{abstract}
Research conducted in the last century suggested that chemoattractants guide cells or their processes to appropriate locations during development. Today, we know that many of the molecules involved in cellular guidance can act as chemorepellents that prevent migration into inappropriate territories. Here, we review some of the early seminal experiments and our current understanding of the underlying molecular mechanisms.
\end{abstract}

\section{Introduction and context}

During development of multicellular animals, many cells or processes that emanate from them need to migrate from their sites of origin to other positions within the animal that are appropriate for their eventual functions. For example, the neural crest cells that later generate the peripheral nervous system and other derivatives migrate from the dorsal neural tube along precise pathways to specific locations within the embryo. Similarly, the axons and dendrites of both central and peripheral neurons often migrate long distances to reach appropriate synaptic partners. Understanding the forces that drive normal development requires learning the cellular and molecular mechanisms by which migrating cells or their processes are guided to appropriate target locations.

Research from the last century by luminaries such as Santiago Ramon y Cajal and Roger Sperry led to the idea that the growing tips of nerve cell axons, called growth cones, are guided to their targets by a process of chemoaffinity [1]. For example, Sperry and his colleagues disrupted the retina in a variety of animals in which retinal axons can regenerate and found that regenerating retinal axons grew back to their appropriate targets in the optic tectum. From these experiments, Sperry proposed that there are attractive signals that guide axons toward appropriate synaptic partners. He further suggested that chemoaffinity was not unique to the retino-tectal system but constituted a general mechanism of axon guidance.
During the ensuing search for molecular mechanisms underlying retino-tectal chemoaffinity, culture experiments from the mid-1980s revealed, surprisingly, that guidance of retinal axons involves repulsive interactions. For example, Friedrich Bonhoeffer and colleagues established a 'stripe assay' in which retinal axons chose between growing on adjacent stripes of membranes derived from either anterior or posterior tectal cells $[2,3]$. The results showed clearly that temporal retinal axons were repelled by posterior tectal cell membranes. Isolation and further study of the responsible molecule, called ephrin, revealed that it is a member of a family that can promote attraction or repulsion and is involved in many normal and pathological processes $[4,5]$.

Are repulsive interactions specific to retinal axons, or are they common during development? Experiments done by Roger Keynes, Kathryn Tosney, and their collaborators suggested that repulsive interactions are a common mechanism for guiding migration. These experiments revealed that migration of motor axons and neural crest cells through the somite is essentially nature's 'stripe assay'. The segmental arrangement of motor axons and migrating neural crest cells arises because these cells are repelled by posterior somites and thus migrate only through anterior somites [6] (reviewed in [7]).

Other hints about cellular mechanisms underlying axon repulsion came from experiments in the lab of Jonathan 
Raper. These studies revealed that when retinal and sympathetic explants were cultured together, growth cones that encountered axons of the other cell type typically lost motility, collapsed, and sometimes began growing in a different direction [8]. The lab isolated a signal capable of causing growth cone collapse from brain membrane extracts in the early 1990s and named it collapsin [9]. Interestingly, collapsin caused the collapse of dorsal root ganglion neuron growth cones; dorsal root ganglion neurons, like sympathetic neurons, are derived from the neural crest. But collapsin did not cause the collapse of retinal growth cones. Collapsin was later found to be a member of a family of signaling molecules called semaphorins, which are now known to regulate a myriad of normal and pathological processes (for recent reviews, see [10-12]).

The many functions of both semaphorins and ephrins have been extensively reviewed [4,5,10-12]. Here, we focus on several recent discoveries about semaphorin $3 \mathrm{~A}$ (the original collapsin-1; Sema3A) [13] and ephrins [14] which provide new insights into the molecular mechanisms underlying growth cone repulsion and how these result in proper nervous system wiring.

\section{Major recent advances}

It has been known for some time that the ability of Sema3A to repel growth cones of cultured Xenopus laevis spinal neurons can be converted to attraction by activation of cyclic nucleotides [15]. Growth cone collapse, retraction, and turning all require cytoskeletal reorganization that depends on regulation of intracellular calcium levels that are mediated through Rho family GTPases [16]. What is the relationship between Sema3A signaling, cyclic nucleotides, intracellular calcium levels, and growth cone repulsion or attraction? Recent studies from the lab of Kyonsoo Hong using cultured $X$. laevis spinal neurons provide important new insights into this question. In an elegant series of experiments, Nishiyama and colleagues [17] discovered that Sema3A not only repels growth cones, but also causes their membranes to become hyperpolarized, whereas attractants such as Netrin and brain-derived neurotrophic factor cause membrane depolarization. Growth cone membrane hyperpolarization requires neuropilin, one of the major classes of semaphorin receptors which often acts together in a complex with the plexin class of receptors $[10,12,18-20]$. This study [17] showed that growth cone membrane hyperpolarization is mediated by chloride entry through channels that are activated by a small increase in intracellular cyclic guanosine monophosphate (cGMP) that follows Sema3A-mediated receptor activation. Membrane hyperpolarization leads to a small elevation of intracellular calcium on the side of the growth cone exposed to Sema3A and to repulsion of the growth cone from the Sema3A source. Importantly, larger increases in intracellular cGMP lead to activation of protein kinase $\mathrm{G}$, which depolarizes the growth cone membrane by activating sodium channels, leading to higher levels of intracellular calcium and converting repulsion to attraction. Thus, changes in levels of cGMP regulate shifts in membrane potential that act as a switch between repulsion and attraction by gating calcium entry into the growth cone.

Neuronal activity and cyclic nucleotide levels have also been shown to be important regulators of ephrin signaling in an in vitro model of retino-tectal map formation developed by Patricia Gaspar and her colleagues [21]. Like semaphorin signaling, signaling by ephrins and their Eph receptors can be either attractive or repulsive and is often mediated through Rho GTPase family effects on the cytoskeleton [4,5]. This study [21] found that oscillations in spontaneous activity are needed for the ephrin-mediated repulsive interactions that cause the elimination of exuberant retinal axons. Retinal growth cones normally collapse and then retract in response to ephrin-A5; however, these responses are prevented by blocking sodium channels with tetrodotoxin. Cyclic adenosine monophosphate (CAMP) can rescue this blockade, but only if it is administered in a periodic fashion, mimicking normal cAMP oscillations.

These and other studies from culture systems suggest that extension to correct targets requires exquisite regulation of growth cone sensitivity to molecules that can act either as repellents or as attractants. What regulates growth cone sensitivity and how does this translate into appropriate pathfinding? Several recent studies provide important new perspectives on this question. Chick motoneurons express the Sema3A receptor, neuropilin1 , and respond to Sema3A from surrounding tissues. Work from the lab of Valerie Castellani showed, surprisingly, that specific populations of chick motoneurons also express Sema3A [22]. Using gain-offunction and loss-of-function experiments, Moret and colleagues [22] found that intrinsic Sema3A decreases the availability of neuropilin-1 at the growth cone membrane, thereby decreasing the sensitivity of motor growth cones to extrinsic Sema3A. This decreased sensitivity enables the growth cones to extend into a region bordered by tissues that express high levels of Sema3A, rather than being entirely repelled from this region, and thus to extend to specific muscle targets. Similarly, interactions between ephrins and Ephs expressed by the same cell have been shown to modulate the response to ephrin-mediated repulsion in cultured retinal axons $[4,23]$. 
Axons of olfactory neurons also have to extend to specific targets and to form a map in the olfactory bulb, although it is different from the topographic map formed by retinal axons in the optic tectum in which axons from a particular part of the retina extend to a specific region of the tectum. In the olfactory map, olfactory neurons each express a single odorant receptor; cells expressing the same receptor can be located anywhere within the olfactory epithelium but their axons all terminate in the same position of the olfactory bulb. New research from the lab of Hitoshi Sakano showed that, in mice, odorant receptors expressed by olfactory neurons regulate production of cAMP and that this in turn regulates expression levels of neuropilin-1 and Sema3A in olfactory growth cones [24]. Thus, axons that express the same odorant receptor also have the same neuropilin or Sema3A expression pattern. Repulsive interactions among neuropilin-expressing and Sema3A-expressing growth cones during pathfinding result in presorting of the axons before they reach their targets, so that axons of cells expressing the same odorant receptor travel together. Sema3A is also expressed by some of the cells surrounding the axons during pathfinding, and this may contribute to proper establishment of the topographic map. A similar mechanism is used during sorting of olfactory axons in fruit flies $[25,26]$, suggesting that this could be a general mechanism for map formation.

Earlier work from the lab of Richard Axel showed that ephrin signaling is involved in formation of the olfactory map [27]. Subpopulations of olfactory neurons that express different olfactory receptors also differentially express ephrin-A5 or ephrin-A3 on their axons. Altering ephrin levels alters formation of the olfactory map; thus, like semaphorins, ephrins are critical for map formation. More recently, elegant work from the lab of Hitoshi Sakano has shown that, like semaphorins, ephrins form part of a neuronal identity code for targeting olfactory axons to the appropriate position in the olfactory bulb [28]. In this case, ephrin-A5 and its receptor, EphA5, are expressed in complementary patterns in axon terminals. These expression patterns are correlated with expression of the cyclic nucleotide-gated channel gene A2 (CNGA2), suggesting that the ephrin and Eph levels are regulated by neuronal activity.

\section{Future directions}

Like any groundbreaking research, these studies raise a host of important questions. For example, what is the relationship between semaphorin signaling and ephrin signaling during formation of the olfactory map? How common is it for a cell to regulate sensitivity to a ligand by co-expressing the ligand and the receptor? In addition to semaphorins and ephrins, there are other repellents, such as slits, that have also been demonstrated to be either repulsive or attractive. Similarly, there are attractants, such as netrins, that have been demonstrated to be either attractive or repulsive. How common is it for this switch between repulsion and attraction to be regulated by activity-mediated changes in membrane polarization? We look forward to learning the answers to these questions from future studies.

\section{Abbreviations}

cAMP, cyclic adenosine monophosphate; cGMP, cyclic guanosine monophosphate; Sema3A, semaphorin 3A.

\section{Competing interests}

The authors declare that they have no competing interests.

\section{Acknowledgments}

The authors thank Andrea Huber and Esther Stoeckli for comments on the manuscript. Research in the lab of CEK is supported by National Institutes of Health (NIH) grants DC009982 and NS050142; research in the lab of JSE is supported by NIH grants NS23915 and HD22486. The authors apologize to the many people whose work in this field could not be included because of space constraints.

\section{References}

I. Sperry RW: Chemoaffinity in the orderly growth of nerve fiber patterns and connections. Proc Natl Acad Sci U S A 1963, 50:703-10.

2. Walter J, Henke-Fahle S, Bonhoeffer F: Avoidance of posterior tectal membranes by temporal retinal axons. Development 1987, $101: 909-13$

3. Walter J, Kern-Veits B, Huf J, Stolze B, Bonhoeffer F: Recognition of position-specific properties of tectal cell membranes by retinal axons in vitro. Development 1987, I 01 :685-96.

4. Egea J, Klein R: Bidirectional Eph-ephrin signaling during axon guidance. Trends Cell Biol 2007, I 7:230-8.

5. Pasquale EB: Eph-ephrin bidirectional signaling in physiology and disease. Cell 2008, I33:38-52.

6. Rickmann M, Fawcett JW, Keynes RJ: The migration of neural crest cells and the growth of motor axons through the rostral half of the chick somite. J Embryol Exp Morphol 1985, 90:437-55.

7. Tannahill D, Britto JM, Vermeren MM, Ohta K, Cook GM, Keynes RJ: Orienting axon growth: spinal nerve segmentation and surround-repulsion. Int J Dev Biol 2000, 44: I 19-27.

8. Kapfhammer JP, Grunewald BE, Raper JA: The selective inhibition of growth cone extension by specific neurites in culture. J Neurosci 1986, 6:2527-34.

9. Luo Y, Raible D, Raper JA: Collapsin: a protein in brain that induces the collapse and paralysis of neuronal growth cones. Cell 1993, 75:217-27.

10. Pasterkamp RJ, Giger RJ: Semaphorin function in neural plasticity and disease. Curr Opin Neurobiol 2009, 19:263-74.

I I. Roth L, Koncina E, Satkauskas S, Cremel G, Aunis D, Bagnard D: The many faces of semaphorins: from development to pathology. Cell Mol Life Sci 2009, 66:649-66.

12. Yazdani U, Terman JR: The semaphorins. Genome Biol 2006, 7:2I I. 
13. Goodman CS, Kolodkin AL, Luo Y, Püschel AW, Raper JA: Unified nomenclature for the semaphorins/collapsins. Semaphorin Nomenclature Committee. Cell 1999, 97:55I-2.

14. Flanagan JG, Gale NW, Hunter T, Pasquale EB, Tessier-Lavigne M: Unified nomenclature for Eph family receptors and their ligands, the ephrins. Eph Nomenclature Committee. Cell 1997, 90:403-4.

15. Song H, Ming G, He Z, Lehmann M, McKerracher L, TessierLavigne M, Poo M: Conversion of neuronal growth cone responses from repulsion to attraction by cyclic nucleotides. Science 1998, 281:1515-8.

FI000 Factor 6.0 Must Read

Evaluated by Marie Filbin 08 Oct 2001

16. Henley J, Poo MM: Guiding neuronal growth cones using $\mathrm{Ca2}^{+}$ signals. Trends Cell Biol 2004, 14:320-30.

17. Nishiyama M, von Schimmelmann MJ, Togashi K, Findley WM, Hong K: Membrane potential shifts caused by diffusible guidance signals direct growth-cone turning. Nat Neurosci 2008, I I:762-71.

FI000 Factor 6.0 Must Read Evaluated by Frank Walsh 09 Oct 2008

18. Kolodkin AL, Ginty DD: Steering clear of semaphorins: neuropilins sound the retreat. Neuron 1997, 19:1159-62.

19. Kruger RP, Aurandt J, Guan KL: Semaphorins command cells to move. Nat Rev Mol Cell Biol 2005, 6:789-800.

20. Raper JA: Semaphorins and their receptors in vertebrates and invertebrates. Curr Opin Neurobiol 2000, 10:88-94.

21. Nicol X, Voyatzis S, Muzerelle A, Narboux-Neme N, Sudhof TC, Miles R, Gaspar P: cAMP oscillations and retinal activity are permissive for ephrin signaling during the establishment of the retinotopic map. Nat Neurosci 2007, 10:340-7.

FI000 Factor 4.8 Must Read Evaluated by Marla Feller 19 Feb 2007, Andrew Chisholm 23 Apr 2007

22. Moret F, Renaudot C, Bozon M, Castellani V: Semaphorin and neuropilin co-expression in motoneurons sets axon sensitivity to environmental semaphorin sources during motor axon pathfinding. Development 2007, 134:449I-50I.

FI000 Factor 3.0 Recommended

Evaluated by Genevieve Rougon I4 Dec 2007

23. Hornberger MR, Dutting D, Ciossek T, Yamada T, Handwerker C, Lang S, Weth F, Huf J, Wessel R, Logan C, Tanaka H, Drescher U: Modulation of EphA receptor function by coexpressed ephrinA ligands on retinal ganglion cell axons. Neuron 1999, 22:73I-42.

24. Imai T, Yamazaki T, Kobayakawa R, Kobayakawa K, Abe T, Suzuki M, Sakano H: Pre-target axon sorting establishes the neural map topography. Science 2009, 325:585-90.

FI000 Factor 3.0 Recommended Evaluated by Michael Crair 16 Sep 2009

25. Lattemann M, Zierau A, Schulte C, Seidl S, Kuhlmann B, Hummel T: Semaphorin-la controls receptor neuron-specific axonal convergence in the primary olfactory center of Drosophila. Neuron 2007, 53:169-84.

26. Sweeney LB, Couto A, Chou YH, Berdnik D, Dickson BJ, Luo L, Komiyama $T$ : Temporal target restriction of olfactory receptor neurons by Semaphorin-I a/PlexinA-mediated axon-axon interactions. Neuron 2007, 53:185-200.

27. Cutforth T, Moring L, Mendelsohn M, Nemes A, Shah NM, Kim MM, Frisen J, Axel R: Axonal ephrin-As and odorant receptors: coordinate determination of the olfactory sensory map. Cell 2003, I | 4:3||-22.

FI000 Factor 6.0 Must Read Evaluated by Lawrence C Katz 0I Sep 2003

28. Serizawa S, Miyamichi K, Takeuchi H, Yamagishi Y, Suzuki M, Sakano $\mathrm{H}$ : A neuronal identity code for the odorant receptor-specific and activity-dependent axon sorting. Cell 2006, 127:1057-69.

FI000 Factor 9.6 Exceptional

Evaluated by Andrew Chisholm 24 Apr 2007, Venkatesh Murthy 27 Apr 2007 